\section{Fruit Firmness of Pickling Cucumber Cultivars}

\author{
Terhi Suojala-Ahlfors
}

AdDitional INDEX wORDs. Cucumis sativus, texture, quality

SUMMARY. Fruit firmness is one of the most important quality aspects in the production of pickling cucumbers (Cucumis sativus) for industry. This study compared the fruit firmness of different cultivars and evaluated the usability of different firmness variables. Firmness of fruit of five to six cultivars from a cultivar experiment was measured penetrometrically over 3 years. The maximum load needed to penetrate the skin, distance at maximum load, load at the end of the measurement, and the mean work during the whole measurement were recorded. Different variables gave a versatile impression of the fruit texture. Although there were some differences in the measured values each year, the ranking of the cultivars was similar each year. Cultivars Celine and Servus had the firmest skin and overall texture. 'Aubade' and 'Carine' had lower skin firmness but the inner part of the fruit of 'Aubade' was very firm. 'Etude' was similar to 'Carine'. 'B2590', measured in only 2 years, had lowest firmness both in skin and flesh. The results show that penetrometric measurement of fruit firmness is a suitable method for analyzing the texture of cucumbers intended for pickling.

$\mathrm{F}$ irmness is an important quality of pickling cucumbers. The pickling process emphasizes the importance of textural properties of the fruit: fruit with poor texture and inadequate firmness at harvest do not produce high-quality products. According to the pickling industry, fruit should have firm and crisp flesh. The skin should be firm, but not leathery.

Fruit firmness is largely determined by genotype. Parthenocarpic cultivars were found to be significantly softer than non-parthenocarpic cultivars (Cook et al., 1994). However, there were larger variations in firmness between cultivars within parthenocarpic and non-parthenocarpic types than between the two types.

Moreover, fertilization, growing conditions during the growing season, fruit size, and storage conditions affect fruit firmness. Firmness has been reported to diminish with increase in fruit size (Mustranta et al., 1976; Thompson et al., 1982). Toward the end of the season, variation in firmness between different size classes diminished (Mustranta et al., 1976). Nutritional and water status of the

MTT Agrifood Research Finland, Plant Production Research, Horticulture, Toivonlinnantie 518, FI-21500 Piikkiö, Finland

Acknowledgments. This study was financially supported by the Finnish Food and Drink Industries' Federation, which is gratefully acknowledged.

“Celine' was sown 5 d later plants may affect fruit firmness. Bakr and Gawish (1993) obtained firmer fruit by spraying plants with potassium chloride and calcium carbonate. The improvement in texture was suggested to be related to enhanced photosynthetic activity and higher content of pectins.

In the postharvest stage, fruit gradually degrade as a result of several cell wall degrading enzymes (Miller et al., 1987). Mechanical damage, ethylene, and improper temperature may enhance the deterioration of the texture and other quality aspects (Bourne, 1982; Miller et al., 1987; Poenicke et al., 1977). Generally, firmness decreases with increasing temperature, but in cucumbers it has been noted that the fruit show a small increase in firmness with increasing temperature (Bourne, 1982). This might be related to the "rubbery" character of fruit stored at high temperature (Miller et al., 1987).

The aim of this study was to compare fruit firmness of different cultivars and to evaluate the usability of different firmness parameters.

\section{Materials and methods}

Cucumber fruit used for measuring firmness originated from the cultivar experiment conducted at MTT Agrifood Research Finland at Piikkiö (lat. $60^{\circ} 23^{\prime} \mathrm{N}$, long. $22^{\circ} 30^{\prime} \mathrm{E}$ ) from 2002 to 2004 . Eleven to 12 cultivars were tested in a randomized completeblock design with four replicate blocks. Some of the cultivars were changed between the years, as they were not considered to be worth further testing. Only the results from the five to six cultivars that were the same each year are reported here. Of the six cultivars, cultivar B2590 (Bejo Zaden, Warmenhuizen, The Netherlands) was not included in 2004, because its quality was not considered good enough for use in Finland.

The growing technique accorded with local practice. Two- to 3-week-old transplants were planted in beds covered with black polyethylene mulch at the beginning of June and covered with fibercloth for 14-23 d (Table 1).

Drip irrigation and fertigation were used after preplant fertilization in the bed. Total nutrient amounts in fertilization were $132 \mathrm{~N}-24 \mathrm{P}-177 \mathrm{~K}$ $\mathrm{kg} \cdot \mathrm{ha}^{-1}$ in $2002,121 \mathrm{~N}-40 \mathrm{P}-197 \mathrm{~K}$ $\mathrm{kg} \cdot \mathrm{ha}^{-1}$ in 2003 , and $128 \mathrm{~N}-40 \mathrm{P}-194 \mathrm{~K}$ $\mathrm{kg} \cdot \mathrm{ha}^{-1}$ in 2004 . The soil was fine sand

Table 1. Dates of sowing, planting, covering, and harvest period in cultivar experiments of pickling cucumber at Piikkiö, Finland, in 2002-04.

\begin{tabular}{lcccc}
\hline Year & $\begin{array}{c}\text { Sowing } \\
\text { date }\end{array}$ & $\begin{array}{c}\text { Planting } \\
\text { date }\end{array}$ & $\begin{array}{c}\text { Duration of } \\
\text { fibercloth cover }\end{array}$ & $\begin{array}{c}\text { Harvest } \\
\text { period }\end{array}$ \\
\hline 2002 & 17 May & 3 June & 3 June-17 June & 11 July-16 Sept. \\
2003 & 20 May & 5-6 June & 5 June-27 June & 10 July-1 Sept. \\
2004 & 17 May & 3 June & 3 June-28 June & 19 July-6 Sept. \\
\hline
\end{tabular}

\begin{tabular}{llll}
\hline $\begin{array}{l}\text { Units } \\
\begin{array}{l}\text { To convert U.S. to SI, } \\
\text { multiply by }\end{array}\end{array}$ & U.S. unit & SI unit & $\begin{array}{l}\text { To convert SI to U.S., } \\
\text { multiply by }\end{array}$ \\
\hline 1.3558 & $\mathrm{ft}-\mathrm{lb}$ & $\mathrm{J}$ & 0.7376 \\
25.4000 & inch $(\mathrm{es})$ & $\mathrm{mm}$ & 0.0394 \\
1.1209 & $\mathrm{lb} / \mathrm{acre}$ & $\mathrm{kg} \cdot \mathrm{ha}^{-1}$ & 0.8922 \\
4.4482 & $\mathrm{lbf}$ & $\mathrm{N}$ & 0.2248 \\
$\left({ }^{\circ} \mathrm{F}-32\right) \div 1.8$ & ${ }^{\circ} \mathrm{F}$ & ${ }^{\circ} \mathrm{C}$ & $\left(1.8 \times{ }^{\circ} \mathrm{C}\right)+32$
\end{tabular}


Table 2. Monthly weather data in the growing seasons 2002-04 and the longterm averages at Piikkiö, Finland.

\begin{tabular}{|c|c|c|c|c|c|c|c|c|}
\hline \multirow[b]{2}{*}{ Month } & \multicolumn{4}{|c|}{ Mean temperature $\left({ }^{\circ} \mathrm{C}\right)^{\mathrm{z}}$} & \multicolumn{4}{|c|}{ Precipitation $(\mathrm{mm})^{\mathrm{y}}$} \\
\hline & 2002 & 2003 & 2004 & $1971-2000$ & 2002 & 2003 & 2004 & $1971-2000$ \\
\hline June & 16.3 & 13.5 & 12.8 & 14.4 & 62 & 67 & 94 & 47 \\
\hline July & 18.7 & 20.1 & 16.0 & 16.6 & 115 & 46 & 136 & 77 \\
\hline August & 18.5 & 16.2 & 16.7 & 15.3 & 9 & 63 & 109 & 78 \\
\hline
\end{tabular}

in 2002 and 2004 and sandy clay in 2003. Fruit were harvested twice a week starting from mid-July and ending after the first night frosts in early or mid-September (Table 1). Weather data from the experimental seasons are given in Table 2.

Sample fruit for measuring firmness were taken twice during the harvesting season, approximately at the middle of the harvesting season (30 July 2002, 4 Aug. 2003, 3 Aug. 2004 ) and near the end of the season (20 Aug. 2002, 18 Aug. 2003, 17 Aug. 2004). Samples consisted of 10 equal-sized fruit per plot. Samples were stored at $6{ }^{\circ} \mathrm{C}$ until the measurements that were performed during the $2 \mathrm{~d}$ following the harvest. The storage time at $6^{\circ} \mathrm{C}$ varied between 2 and 24 h. Weight, length, and diameter of each fruit were measured. The average diameter of the fruit was $32-39 \mathrm{~mm}$ at different measuring times.

Fruit firmness was measured penetrometrically with a motorized materials testing device (LRX, Lloyd Instruments Ltd., Fareham, England) equipped with a $100-\mathrm{N}$ load cell and a cylindrical probe $4.8 \mathrm{~mm}$ in diameter and with blunt end. The probe was set to penetrate the fruit at a rate of $10 \mathrm{~mm} \cdot \mathrm{min}^{-1}$ for a distance of $15 \mathrm{~mm}$, and it measured the resistance to shear force. An intact fruit was set longitudinally to the measuring plate and the probe entered the middle part of the fruit through the skin. The maximum load (Newtons) needed to penetrate the skin, distance $(\mathrm{mm})$ at which the maximum load was achieved, the mean work (Joules) recorded in the whole measurement, and load (Newtons) at the end of measurement at $15-\mathrm{mm}$ distance were used as the response factors. Measurements were performed at room temperature.

The response variables were analyzed statistically by a mixed model for repeated measures, including cultivar, date, and their interaction as the fixed factors; and block, block $\times$ cultivar, and block $\times$ date interactions as the random factors. Cultivars were further compared by contrast, using 'Carine' (Seminis, Oxnard, Calif.) as the standard cultivar against which the others were contrasted. The SAS MIXED procedure (Littell et al., 1996) was used to fit the model by the restricted maximum likelihood (REML) estimation method. Residual analyses did not indicate any cross departures from the assumptions of the models.

\section{Results and discussion}

Figure 1 illustrates an average force-distance curve for 'Carine'. The curves for all cultivars have a similar shape but the height of the maximum load peak is somewhat different, as well as the load at the end of the measurement. The curves show visually the decrease in firmness from the skin to the inner parts of the fruit. This is in concordance with the findings by Thompson et al. (1982), who measured as much as five times higher firmness in mesocarp compared to endocarp tissues in fruit of 4 - to 5 - $\mathrm{cm}$ diameter.
According to the statistical analyses, cultivars showed clear differences in all variables related to firmness (Fig. 2, Table 3 ). There were some significant interactions between cultivar and date in 2002 and 2003, but these were mostly due to different magnitudes of differences, and not due to discrepancies in the properties of the cultivars. The date of analysis affected most of the variables.

Interpretation of the maximum load is easiest: it is the direct measure of skin firmness. Each year, cultivars Celine and Servus had higher maximum load values than 'Carine', and 'B2590' had lower values than 'Carine' in 2002 and 2003 (Fig. 2). In 2002 the maximum load of 'Etude' was also significantly lower than that of 'Carine'.

Distance at which the maximum load was registered was low in the fruit of 'Carine'. Distance was higher in 'Celine', 'B2590', 'Servus', and 'Etude' (in 2004) compared to 'Carine'. The maximum peak for the fruit of 'Aubade' was at a lower distance than 'Carine' in 2004.

Load at the end of the measurement is a momentary load value, describing the firmness of the inner part of the fruit. 'Aubade' consistently had the highest values. 'Servus' had the second firmest flesh but the difference between it and 'Carine' was statistically significant only in 2004 . 'B2590' clearly had the lowest load at the end of the measurement in both years.

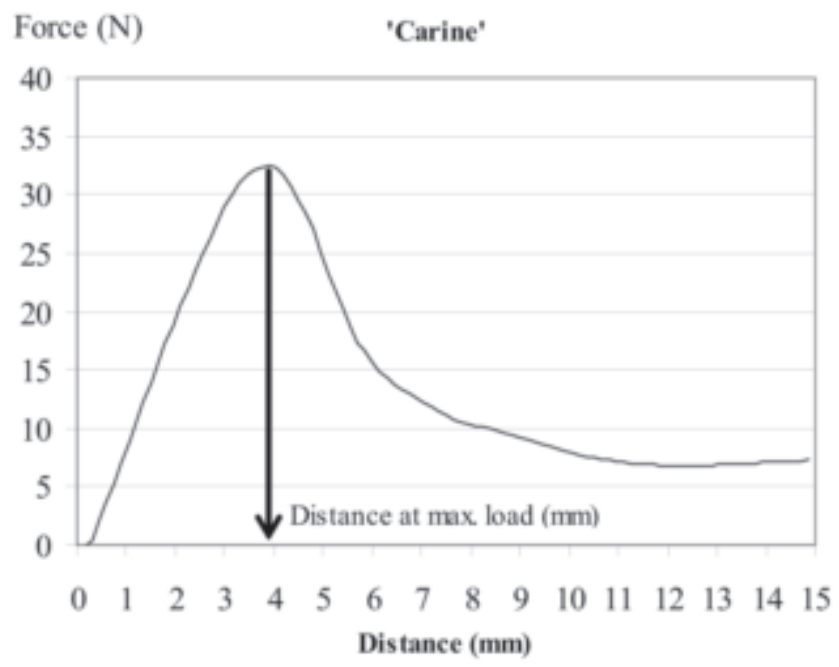

Fig. 1. Force-distance curve of the standard pickling cucumber cultivar Carine as average over all measurements in $2002-04(n=240)$. The arrow indicates the distance from the start of the measurement at which the maximum force needed to penetrate the fruit was recorded $(1 \mathrm{~mm}=0.0394 \mathrm{inch}, 1 \mathrm{~N}=0.2248 \mathrm{lbf}$ ). 

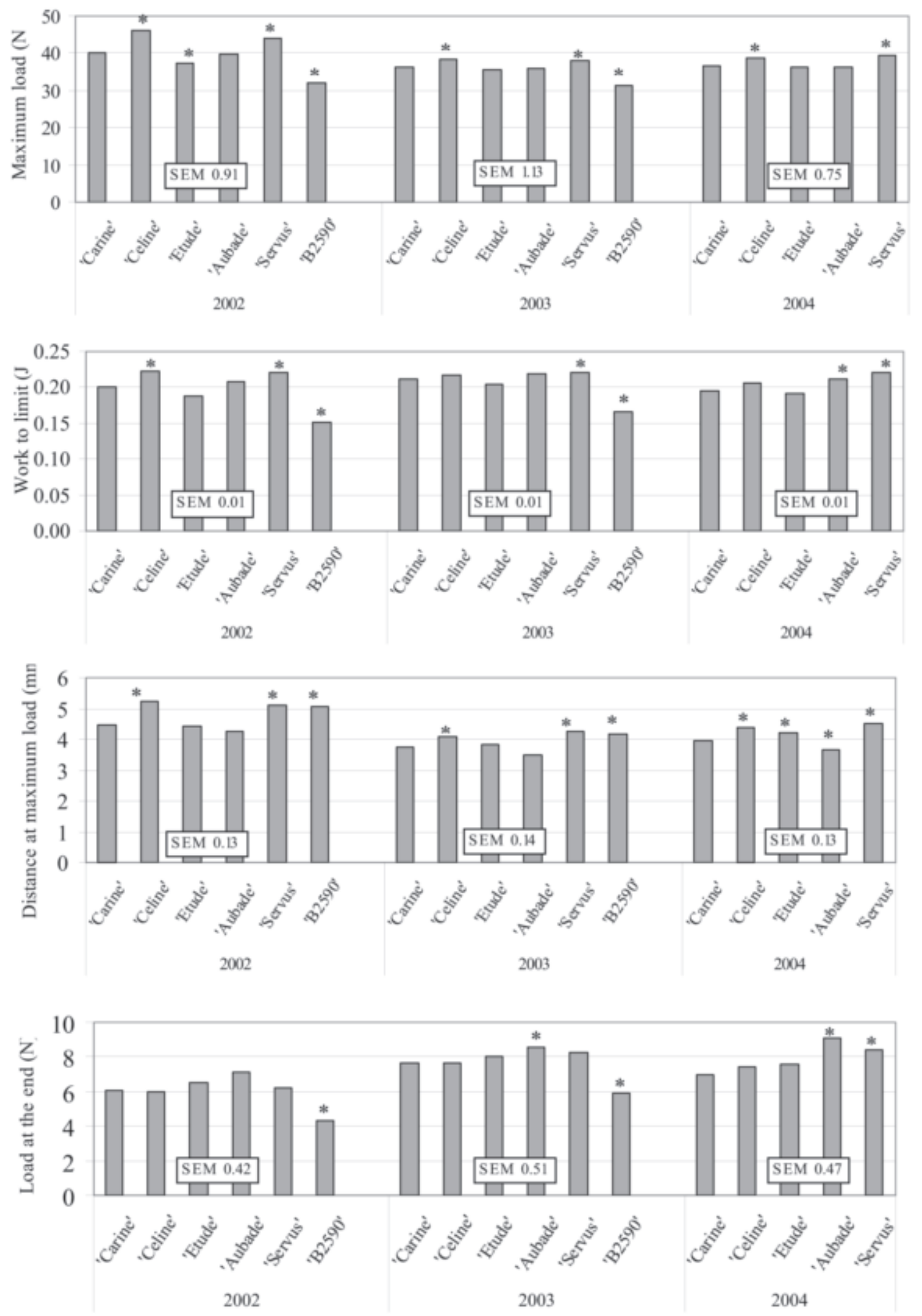

Year and cultivar

Fig. 2. Firmness variables of different pickling cucumber cultivars in 2002-04 averaged over two measurement dates. Asterixes indicate a statistically significant difference $(P<0.05)$ to the standard cultivar Carine. There were four replications at each measuring time and 10 fruit in each replication $(1 \mathrm{~N}=0.2248 \mathrm{lbf} ; 1 \mathrm{~J}=0.7376 \mathrm{ft}-1 \mathrm{~b} ; 1 \mathrm{~mm}=0.0394)$. 
Table 3. Probabilities of fixed factors in statistical analyses of pickling cucumber cultivar experiments in 2002-04.

\begin{tabular}{|c|c|c|c|c|}
\hline \multirow[b]{2}{*}{$\begin{array}{l}\text { Year and } \\
\text { factor }\end{array}$} & \multicolumn{2}{|c|}{ Firmness variable } & \multirow[b]{2}{*}{$\begin{array}{c}\text { Load at } \\
\text { the measurement } \\
\text { maximum }(\mathrm{N})\end{array}$} & \multirow[b]{2}{*}{$\begin{array}{c}\text { Mean } \\
\text { work } \\
(\mathrm{J})^{\mathrm{x}}\end{array}$} \\
\hline & $\begin{array}{l}\text { Maximum } \\
\text { load } \\
(\mathrm{N})^{\mathrm{z}}\end{array}$ & $\begin{array}{l}\text { Distance at } \\
\text { the end of } \\
\text { load }(\mathrm{mm})^{\mathrm{y}}\end{array}$ & & \\
\hline \multicolumn{5}{|l|}{2002} \\
\hline Cultivar (C) & $<0.001$ & $<0.001$ & 0.002 & $<0.001$ \\
\hline Date (D) & $<0.001$ & 0.070 & $<0.001$ & 0.008 \\
\hline $\mathrm{C} \times \mathrm{D}$ & $<0.001$ & 0.516 & 0.620 & 0.026 \\
\hline \multicolumn{5}{|l|}{2003} \\
\hline $\mathrm{C}$ & $<0.001$ & $<0.001$ & $<0.001$ & $<0.001$ \\
\hline $\mathrm{D}$ & 0.830 & $<0.001$ & 0.011 & 0.010 \\
\hline $\mathrm{C} \times \mathrm{D}$ & 0.013 & 0.032 & 0.883 & 0.645 \\
\hline \multicolumn{5}{|l|}{2004} \\
\hline C & 0.005 & $<0.001$ & $<0.001$ & 0.006 \\
\hline $\mathrm{D}$ & 0.125 & $<0.001$ & 0.005 & 0.022 \\
\hline $\mathrm{C} \times \mathrm{D}$ & 0.532 & 0.192 & 0.564 & 0.693 \\
\hline
\end{tabular}

Mean work is the description of the texture over the total $15-\mathrm{mm}$ distance. It is the combination of the texture of both the skin and the inner parts. Although it is much affected by the maximum load caused by the skin, it gives complementary information on the texture. Therefore it showed similar trends to maximum load, with 'Celine' and 'Servus' having the highest values. However, the high under-skin firmness of 'Aubade' raised its total work values, which showed a statistically significant difference from 'Carine' in 2004.

The general impression of the texture of the cultivars was very similar each year. Cultivars Celine and Servus had the firmest skin and overall texture. 'Aubade' had similar skin firmness to 'Carine', but the inner part of the fruit was very firm. 'B2590', measured only in 2002 and 2003, clearly had the lowest firmness both in skin and in flesh. 'Etude' was similar to 'Carine', which was the cultivar representing medium firmness.

Fruit firmness varied between the measurement dates. This might be related to the developmental and physiological state of plants at harvest, but it is probably more related to the differences in fruit size. Each year, the firmness of fruit flesh, indicated by the load at the end of the measurement, was higher in the smaller-sized fruit, as reported by Mustranta et al. (1976) and Thompson et al. (1982). In 2002, the load at the end of the measurement was higher on the first analysis date, the mean weight of the fruit being 90 $\mathrm{g}$. The maximum load and mean work were higher on the second date, when the mean weight of fruit was $99 \mathrm{~g}$ (SE $=2.0 \mathrm{~g}$ ). In 2003 , there was a larger difference in the mean weight of fruit, which was $111 \mathrm{~g}$ on 4 Aug. and $75 \mathrm{~g}$ on 18 Aug. $(\mathrm{sE}=3.0 \mathrm{~g})$. On the latter date, load at the end and mean work were higher than on the first date, and distance at maximum load was lower. Therefore, the smaller fruit from the latter date had the firmer texture. In 2004 , fruit were smaller than in the previous years, the mean weight being $82 \mathrm{~g}$ on 3 Aug. and $73 \mathrm{~g}$ on 17 Aug. $(\mathrm{SE}=2.1 \mathrm{~g})$. Distance at maximum load was higher at the first date, whereas load at the end and mean work were higher at the second date. The maximum load was similar on both dates. There were no statistically significant differences in fruit weight or fruit diameter between the cultivars.

Differences between the cultivars, in maximum load and mean work in particular, were largest in 2002 and smallest in 2004. In the latter year this was partly due to the fact that 'B2590', which had the least firm texture, was not included in the experiment. However, differences between the other cultivars were also more pronounced in 2002. For example, 'Celine' had, in relation to other cultivars, a firmer texture in 2002. The effect of year might be related to weather condi-
Table 4. Total fruit yield of pickling cucumber cultivars during the whole harvest season in 2002-04.

\begin{tabular}{lccc}
\hline & \multicolumn{3}{c}{ Total yield } \\
& $\left(\mathbf{1 0 0 0} \mathbf{~ k g} \cdot \mathbf{h a}^{-1}\right)^{\mathrm{z}}$ \\
\cline { 2 - 4 } Cultivar & $\mathbf{2 0 0 2}$ & $\mathbf{2 0 0 3}$ & $\mathbf{2 0 0 4}$ \\
\hline Carine & 73.4 & 66.8 & 60.5 \\
Celine & 81.0 & 67.7 & 58.0 \\
Etude & 80.3 & 66.5 & 57.2 \\
RZ12-18 & 80.9 & 66.5 & 60.3 \\
Servus & 79.7 & 67.4 & 53.8 \\
B2590 & 88.8 & 73.3 & \\
SE & 3.15 & 4.42 & 1.96 \\
$P^{y}$ & 0.037 & 0.806 & 0.139 \\
\hline "1000 kg.ha ${ }^{-1}=892.2 \mathrm{lb} /$ acre. \\
yProbability value of cultivar in the analysis of vari- \\
ance.
\end{tabular}

tions. The growing season 2002 was the warmest of the experimental years and 2004 was the coldest. Therefore, the fruit texture of different cultivars might be more variable in years with high temperatures, which result in high growth rates and high transpiration. Sajnín et al. (2003) reported that good turgor status was associated with high fruit firmness. Mustranta et al. (1976) also found that the differences in firmness between different size classes of fruit were greatest in warm and dry growing seasons. The magnitude of variation may also be related to the characteristics of the growing site and cultivation technique. Despite the annual variation, the ranking of the cultivars with regard to fruit firmness remained similar each year.

'B2590', which had the softest texture, was the highest-yielding cultivar in 2002 and 2003, although the effect was statistically significant only in 2002 (Table 4). The high yield was largely due to the high productivity in the early period of the harvesting season. Although there is insufficient data to draw any firm conclusions, it would be worth further studies to see if high and early yield production is related to low firmness in fruit.

To conclude, fruit firmness of different cultivars showed similar trends each year, so it seems to be a stable cultivar characteristic. Within the cultivars, fruit size has an effect on firmness of fruit flesh, being higher in the small-sized fruit. In the warm growing seasons, the variation in fruit texture seems to be more variable than in cool seasons. 


\section{Literature cited}

Bakr, A.A. and R.A Gawish 1993. Technological aspects of keeping and pickling qualities of cucumbers as influenced by fertilizers. Plant Foods Human Nutr. 44:17-28.

Bourne, M.C. 1982. Effect of temperature on firmness of raw fruits and vegetables. J. Food Sci. 47:440-444.

Cook, K.L., J.R. Baggett, and A.C. Gabert 1994. Fruit firmness and quality of parthenocarpic versus nonparthenocarpic pickling cucumber cultivars. Cucurbit Genet. Coop. Rpt. 17:30-34.

Miller, A.R., J.P. Dalmasso, and D.W. Kretchmann 1987. Mechanical stress, storage time, and temperature influence cell wall-degrading enzymes, firmness, and ethylene production by cucumbers. J Amer. Soc. Hort. Sci. 112:666-671.

Mustranta, A., M. Kiesvaara, and T. Kuusi 1976. Pectolytic changes in the composition of cucumbers during the period of harvest. J. Sci. Agr. Soc. Finland 48:407-414 (in Finnish, English abstract).

Littell, R.C., G.A. Milliken, W.W. Stroup, and R.D. Wolfinger 1996. SAS system for mixed models. SAS Inst., Cary, N.C.

Poenicke, E.F., S.J. Kays, D.A. Smittle, and R.E. Williamson 1977. Ethylene in relation to postharvest quality deterioration in processing cucumbers. J. Amer. Soc. Hort. Sci. 102:303-306.

Sajnín, C., G. Gamba, L.N. Gerschenson, and A.M. Rojas 2003. Textural, histological and biochemical changes in cucumber (Cucumissatious L.) due to immersion and variations in turgor pressure. J. Sci. Food Agr. 83:731-740.

Thompson, R.L., H.P. Fleming, D.D. Hamann, and R.J. Monroe 1982. Method for determination of firmness in cucumber slices. J. Texture Studies 13:311-324. 